\title{
FRANKLIN INSTITUTE
}

(Proceedings of the Slated Meeting held Wednesday, May 57 , roti.)

HaLl of the Frankin Institute,

Philadelphia, May 17, I9II.

President WaLton ClakK in the Chair.

Additions to membership since last report, 2.

Joseph S. Hepburn, A.M., M.S., presented the paper of the evening, entitled "The Handling, Transportation, and Storage of Perishable Foodstuffs. A review of the Work of the U. S. Food Research Laboratory."

An outline of the work of the laboratory was given from its establishment several years ago to the present time. The apparatus and equipment first installed and those now in use were cescribed in detail, as well as the chemical, bacteriological, and histological investigations made in contrection with the study of poultry.

The effect of low temperatures and storage on the tissues and muscles of poultry were shown by means of photomicrographic slides. Numerous lantern slides illustrating the best methods of killing and preparing poultry for the market, the most approved manner of packing and shipping, and recent practice in cold storage, were exhibited.

The thanks of the meeting were extended to the speaker. Adjourned.

R. B. OWENS,

Secretary.

\section{COMMITTEE ON SCIENCE AND THE ARTS.}

(Abstract of Proceedings of the Stated Meeting held Wednesdoy, May 3, IgTr.)

- Hall of the Franklin Institute, Philadelfhia, May 3, igil.

DR. Geor. A, HoddLey in the Chair.

The following reports were presented for fitsal action:

No. 2455-Hardinge Conical Ball and Pebble Mill. Certificate of Merit. Adopted.

No. 2458--Colby Electric Furnace for Melting Metals. Scott award. Adopted.

No. 2479-Behrend High Speed Electric Generators. Scott award. Adopted.

No. 250I.-Woli Liquid Gas Apparatus and Process. Scott award. Adopted.

R. B. OWENS,

Secretary. 